\title{
Utilization of Interactive Multimedia in Improving the Quality of Learning During the Covid-19 Pandemic
}

\author{
AB Sarca Putera ${ }^{1 *}$ and Nurlizawati ${ }^{2}$ \\ ${ }^{1}$ Dep. of Sociology Education, Faculty of Social Sciences, Universitas Negeri Padang, Indonesia \\ ${ }^{2}$ Dep. of Sociology Education, Faculty of Social Sciences, Universitas Negeri Padang, Indonesia \\ *Corresponding author. Email: absarcaputera@fis.unp.ac.id
}

\begin{abstract}
The study examines the interactive multimedia development by using Android systems. The interactive multimedia development is an important thing that supports online learning, as is happening now. Media in process of teaching and learning is an important element to deliver information to be more interesting and meaningful for students. Research and Development (R\&D) with the $4 \mathrm{D}$ development model is used as a method in this study. They are: (1) Define (defining); (2) Design (design); (3) Develop (development); (4) Disseminate (spread). The study indicates that the use of android-based interactive multimedia can improve communication skills in learning. This paper can be a choice of literature in understanding the use of android-based interactive multimedia in sociology learning.
\end{abstract}

Keywords: Interactive Multimedia, Android, Communication

\section{INTRODUCTION}

The spread of the Covid-19 virus has not been resolved until now. Meanwhile, the pandemic conditions have brought urgent changes to various sectors, especially in education. Responding to these conditions, several circulars issued by the Ministry of Education and Culture. Such as the circulars Number 3 of 2020 regarding the Corona Virus Disease (COVID19) Precaution in Education Unit and the Circulars Number 36962/MPK.A/HK/2020 concerning Online Learning and Work from Home to Prevent the Corona Virus Disease (COVID-19) spreads. Based on that, to stave off the virus spreads, teaching and learning activities switched to online. Learning that is carried out from home is known as Belajar dari Rumah (BDR) or Learning from Home, but people often refer to it as online learning.

Changing learning patterns certainly really need the role of teachers in overcoming learning difficulties through the Covid-19 pandemic. According to discussions results through webinars conducted by the Department of Sociology UNP, which is attended by Sociology teachers, it is obtained data that teachers experience difficulties in designing effective learning for students during online learning. First, students do not have adequate access to online learning, secondly learning is mostly based on assignments, it feels less interactive with students, third is the difficulty of evaluating online learning, fourth is not achieving learning goals (Berbagi Pengalaman Pembelajaran
Daring di Masa Pandemi COVID-19, Discussion Note), Juli, 18, 2020).

The fundamental problem in the online learning process is that the interaction pattern has changed, from face-to-face to virtual-face interactions. This condition significantly affects the activeness of students in learning, so that in the end, it will affect the learning assessment process. The problem of student activeness in learning requires the role of the teacher to be able to overcome this problem. One way to increase student activity in online learning is to use interactive multimedia.

Learning media is anything that can convey or distribute information effectively and efficiently in learning activities. Also, learning media can provide the same stimulation, provide the same experience, and cause the same perception (Munadi, 2008). The selection of the right learning media affects realizing the achievement of learning objectives.

Interactive learning media is potentially high to encourage students to deliver a positive respond from the learning material. One of the learning media is computers (Istiqlal, 2017). Arsyad (2011) classifies the meaning of media into two things, namely physical and non-physical definitions. The physical includes the object which can be heard, seen, or touched with the five senses. Meanwhile, the non-physical definition is the content on the hardware which conveyed to students. The proper learning media must have some of requirements. Such as increasing learner motivation, aims to motivate learners, and stimulate learners to 
memorize the material learning, also provide a stimulus to learn.

Sociology learning still tends to be less in utilizing computer media for the development of learning materials. To overcome media limitations, the role of the teacher is needed to make interactive multimedia. Therefore, computers rely on teacher as a facilitator to devise the sociology learning media.

Several studies show that the traditional methods in teaching such as books or films, is not as better as computers (Alessi \& Trollip, 2001). Consequently, learning media development can be done by computers and all the media which resulting from it will be more effective to deliver the subject and also efficient to allocate time and energy.

Therefore, researchers are interested in researching the development of interactive multimedia in increasing sociology learning activities in schools. The importance of developing interactive multimedia is to create an interactive learning atmosphere, which can improve students' ability to communicate. Therefore, researchers are interested in conducting flash-based interactive multimedia development research for Android in Sociology subjects.

\section{RESEARCH METHOD}

Research and Development (R\&D) with the 4 D development model is used as a method in this study. According to Thiagarajan, Semmel, and Semmel (1974: $5)$, the $4 \mathrm{D}$ development model (4D Models) are: (1) Define (defining); (2) Design (design); (3) Develop (development); (4) Disseminate (spread). The study is intended to develop interactive multimedia on Android system as tools in sociology learning.

Defining the learning requirements is the aim of define stage. It includes: Front end analysis aims to raise and determine the problems in learning so that the teaching materials development is needed. Through the analysis, the facts descriptions, expectations, and the alternative of solutions to fundamental problems will be obtained, making it easier to determine or select the teaching materials developed.

Map out and compile learning tools and data collection instruments are the design stage aims. The Develop stage consists of validation by expert and practitioner validators, product development tests, and revisions. The Disseminate stage was carried out by providing a limited soft file for the final results of Flash Interactive Multimedia for Android to high school sociology teachers in Padang. Given the limitations in research, the disseminated stage will be carried out in future research.

Students at SMA Negeri 5 Padang in a limited test became the subject in this study. Qualitative data were obtained from the validation results of expert validator's suggestions and practitioners, as well as comments or suggestions for revised materials in student response. The quantitative data from this study were obtained from: The results of validation by expert validators and practitioners, in the form of media validation questionnaire scores on a scale of 1 to 5 , for each criterion. The scale includes; $1=$ Not Good, $2=$ Not Good, 3 = Fair, 4 = Good, and 5 = Very Good.

Data about students' responses to the media are described in student response questionnaire scores on 1 to 4 scales for each criterion. The scale includes; $1=$ Strongly Disagree (STS), 2 = Disagree (TS), 3 = Agree (S), and $4=$ Strongly Agree (SS).

Data about students' communication skills in communication skills questionnaire scores on a scale of 1 to 4 for each criterion. The scale includes; $1=$ Strongly Disagree (STS), 2 = Disagree (TS), 3 = Agree (S), and $4=$ Strongly Agree (SS).

Validation Questionnaire and Student Communication Skills Questionnaire are the instruments which used in collecting the data in this study. Descriptive qualitative used as data analysis techniques by collecting qualitative data consisting of validation by expert validators, practitioners, and comments or suggestions from student responses. The results of analysis data is used as a material for the revision of the media being developed. Product validation questionnaire data is obtained from expert validators and practitioners assessments in the form of a questionnaire score in each criteria for the validation of flash interactive multimedia on Android in a scale of 1 to 5 .

\section{RESEARCH RESULTS}

This research has succeeded in developing interactive multimedia in sociology learning based on Android. Inside interactive multimedia, there is Sociology learning material about Social Groups. Also, in interactive multimedia, there are evaluation and practice questions.

Before being assessed by interactive multimedia by material and learning experts, media experts and students (large and small classes), was previously consulted with media experts and sociology teachers to get input. Then, the input results used as revision material.

It was followed by an interactive multimedia assessment by material and learning experts, media experts, and students (small classes and extensive classes). This android-based interactive multimedia product underwent revisions after being validated by material and learning experts, media experts, students (small classes, and large classes). 
Interactive multimedia was then revised based on input from material and learning experts (Sociology teachers), media experts, and students. Android-based interactive multimedia that has been assessed and given suggestions and input by the assessor is then revised. After being revised and multimedia was declared feasible, Android-based interactive multimedia for sociology learning was produced.

Constraints faced by researchers in developing multimedia tools interactively by using an Android is the ability to create it, which is very limited because they are not experts in this matter, and difficult to find finding media references.

This learning multimedia is made by fundamental and basic competencies in Sociology subject Class X. 2\% with a useful predicate, (b) the result of the design expert trial, the overall percentage average of the test questionnaire is $80.9 \%$ with a useful predicate, (c) according to the material proficient trial results, an overall average percentages from the testing questionnaire is $85.7 \%$ with a useful predicate, (d) the results of the small-scale trial, the overall percentage of the test questionnaire was obtained an average The overall percentage average of the test questionnaire was $82 \%$ with a useful predicate. Based on the experimental data obtained, the development of multimedia learning in the $\mathrm{X}$ class sociology subject can be said to be feasible to be applied in schools.

In general, the learning multimedia has several advantages, namely exciting and fun, because it is presented by adjusting the characteristics of students. It starts from the use of display colours, images, simple animation effects, and sound effects, so it is not dull for users. This learning multimedia is easy to use by users with simple commands, and users can actively select the desired menu. The practice questions contained in this learning multimedia are displayed not in order to minimize the possibility of students memorizing answers. And the evaluation report can be printed according to the student's score. Apart from having several advantages, this learning multimedia also has weaknesses or weaknesses, namely multimedia learning products cannot be accessed online and is only intended for class $\mathrm{X}$ students in semester one. When students enter the second semester, they must be remade with new multimedia learning products.

On educational criteria, the material on interactive multimedia is by the Content Standards, then the material presented is attractive using a deductive approach. The goal is to improve students' ability to communicate. Overall, interactive multimedia is quite exciting and can improve students' skills in communicating.

\section{CONCLUSION}

The output media produced in this research is interactive multimedia based on Android flash system for Sociology subject in Class X Semester 1. This interactive multimedia was developed with a 4D development model. According to Thiagarajan, Semmel and Semmel (1974: 5), the 4 D developments are (1) Define (definition); (2) Design (design); (3) Develop (development); (4) Disseminate (dissemination). This study conducted a trial phase for media and material experts, learning, and involved students at small classes.

Suitability of learning media based on the results of large-scale trials, the overall percentage average of the test questionnaire was $82 \%$, with a useful predicate. So this flash-based interactive multimedia for Android is appropriate to use as a medium or learning sociology tools in high school students.

This research is a development research. the researcher suggests that interactive multimedia based on flash for Android that has been developed needs to be tested on an ongoing basis in Sociology learning activities for students in a high school. This is to determine the students understanding's level in advantages and disadvantages of interactive multimedia so it worth of being used as a learning resource.

\section{REFERENCES}

[1] Alessi, S.M., \& Trollip, S.R. 2001. Multimedia for Learning Method and Development. Needham Heights: Allyn \& Bacon

[2] Arsyad, Azhar. 2011. Media Pembelajaran. Jakarta: PT Grafindo Persada.

[3] Muhammad Istiqlal. 2017. Pengembangan Multimedia Interaktif Dalam Pembelajaran Matematika. Jurnal Ilmiah Pendidikan Matematika Volume 2 Nomor 1 P-ISSN: 2502-7638; E-ISSN: 2502-8391. Institut Agama Islam Negeri Salatiga.

[4] Munadi, Yudhi. 2008. Media Pembelajaran, Sebuah Pendekatan Baru. Jakarta: Gaung Persada Press.

[5] Thiagarajan, Sivasailam., Semmel, Dorothy S., \& Semmel, Melvyn I. (1974). Instruction Development for Training Teachers of Exceptional Children. Bloomington: Indiana University.

[6] Surat Edaran Mendikbud Nomor 3 Tahun 2020 Tentang Pencegahan COVID-19 pada Satuan Pendidikan

[7] Surat Mendikbud Nomor 36962/MPK.A/HK/2020 Tentang Pembelajaran secara Daring dan Bekerja dari Rumah dalam Rangka Pencegahan Penyebaran Corona Virus Disease (COVID- 19). 